\title{
Litwa nad Wartą? Wokół pierwszego pomysłu Pana Tadeusza
}

\section{Lithuania on the Warta river? Around the first idea of Pan Tadeusz}

\author{
|| Elżbieta Lijewska
Uniwersytet im. Adama Mickiewicza w Poznaniu
}

\begin{abstract}
The article refers to the hypothesis that Pan Tadeusz by Adam Mickiewicz had its origins in Wielkopolska (Greater Poland region). It reminds the source of the hypothesis and the attitude of researchers of the 19th and 20th centuries towards it. The author emphasises the significance of the fact that Mickiewicz met his brother Franciszek, and some other Lithuanians, in Łukowo on the Warta river. The author of this article draws our attention to an older version of the beginning of the poem entitled Żegota and connects the version with Ignacy Domeyko.
\end{abstract}

Key words: Adam Mickiewicz, Pan Tadeusz, Ignacy Domeyko, November Uprising (1830-1831)

Streszczenie: Artykuł nawiązuje do hipotezy wielkopolskich początków Pana Tadeusza Adama Mickiewicza. Przypomina źródła tej hipotezy oraz stanowiska wobec niej badaczy w wieku XIX i XX. Autorka podkreśla znaczenie spotkania z bratem, Franciszkiem Mickiewiczem oraz innymi Litwinami podczas pobytu poety w Łukowie nad Wartą. Zwraca uwagę na starszą wersję początku poematu, zatytułowanego Żegota, i wiąże ją z osobą Ignacego Domeyki.

Słowa kluczowe: Adam Mickiewicz, Pan Tadeusz, Wielkopolska, Ignacy Domeyko, powstanie listopadowe

JanuszRuszkowski,kronikarzpobytuAdama MickiewiczawWielkopolsce, zwracał kiedyś uwagę na pewną zadziwiającą sytuację dotyczącą tego okresu życia poety. Z jednej bowiem strony żadnemu fragmentowi biografii Mickiewicza nie poświęcono tylu osobnych publikacji, z drugiej natomiast badania te mają prawie wyłącznie charakter regionalny, tak jakby siedem miesięcy spędzonych w Poznańskiem (sierpień 1831 - luty 1832) interesowało tylko Wielkopolan. Zauważał, że sytuacja ta owocuje ujęciami skrajnymi: „albo marginalizacją tematu, albo jego swoistą apokryfizacją” (Ruszkowski 1998, 247). Tę diagnozę można by odnieść na przykład do 
tzw. łukowskiej (czy szerzej - wielkopolskiej) hipotezy pierwszego pomysłu Pana Tadeusza.

Adam Mickiewicz przybył w sierpniu 1831 do Wielkopolski, by stąd przedostać się do Królestwa Polskiego i wziąć udział w powstaniu listopadowym. Droga do Warszawy była już wówczas odcięta i poeta pozostał w Wielkim Księstwie Poznańskim goszczony w ziemiańskich pałacach i szlacheckich dworkach. Na dłużej zatrzymała go tam wiadomość o losie brata, Franciszka Mickiewicza, uczestnika powstania. Badacze dość zgodnie podkreślają, iż spotkanie z nim w Łukowie, małej miejscowości nad Wartą na północ od Poznania, było momentem przełomowym w Wielkopolskim „epizodzie" Mickiewicza, wyrwało poetę z ciężkiego smutku, a może i dostarczyło impulsów do literackiej pracy. Trzeba tu przypomnieć kilka faktów. Józef Ignacy Grabowski Goetzendorf, właściciel Łukowa, były oficer napoleoński, dyrektor Ziemstwa Kredytowego, był ważną osobą w Wielkim Księstwie Poznańskim. Podczas powstania listopadowego organizował przerzuty powstańców, a także broni i pieniędzy przez Księstwo. To on na prośbę Mickiewicza wydobył Franciszka Mickiewicza z obozu internowania pod Elblągiem i sprowadził do siebie. W kalendarzu familijnym odnotował pod datą 23 [grudnia] 1831: „Przybył do naszego domu przyjaciel nasz Franciszek Mickiewicz i zastał u nas bawiącego brata Adama” (Maciejewski 1972, 525). Tradycja rodzinna i miejscowa zachowała jeszcze takie szczegóły przyjazdu:

Przyjazd pana Franciszka do Łukowa odbył się około Bożego Narodzenia 1831 r. i to w ten sposób, że za bryczką, która wiozła niedawnego ułana, szła luzem ulubiona jego „kasztanka”, wierna towarzyszka jego trudów wojennych - a na drugiej bryczce, w towarzystwie Wojtkiewicza i Wiewiórkowskiego, również jak p. Franciszek rozbitków wojskowych, siedział Wincenty Pol, oficer 10-go pułku ułanów litewskich (Bełza 1890, 188) ${ }^{1}$.

Nieco później, już w styczniu 1832 roku, zawitał do Łukowa inny powstaniec, pochodzący z Galicji Kajetan Rzepecki:

Pan Gr[abowski] kazał mnie swym ekwipażem odwieźć do Łukowa, dając mi list rekomendacyjny do swojej małżonki, która mnie zaraz kazała odprowadzić do oficyny, gdzie było ulokowanych piętnastu powstańców litewskich, niby to oficerów, którzy wszyscy byli ubrani po cywilnemu. Pomiędzy którymi też był i Franciszek Mickiewicz, brat Adama znanego poety! (...) Ci gdy mnie ujrzeli, kiedy mnie służący pomiędzy nich przyprowadził, widząc mnie w mundurze, zaczęli mnie mierzyć od stopy aż do wierzchu czupryny! Kilku zapraszało mnie, abym z nimi usiadł

${ }^{1}$ Relacja ta oparta jest na liście pisanym przez Adama Grabowskiego, syna Józefa, do Antoniego Małeckiego w 1842 (Mann 1904, 204). Wątpliwość może budzić obecność Wincentego Pola w tym czasie w Łukowie, według innych źródeł poznał on Mickiewicza dopiero w Dreźnie (Dernałowicz 1966, 54). Jednak sam Pol podawał interesujące szczegóły dotyczące pobytu Mickiewicza w Wielkopolsce, szczególnie w Łukowie, np. to, że poeta przebywał tam pod nazwiskiem Justyna Pohla, że zrażał do siebie Wielkopolan hardym charakterem (Pol 1871, 144). Wg Ruszkowskiego Pol przebywał w Łukowie w styczniu 1832 i zdobył te informacje z pierwszej ręki (Ruszkowski ok. 1998, 196-197). Być może w rodzinnych wspomnieniach Grabowskich stopiło się w jedno zdarzenie przyjazd dwóch „bryczek”: jednej przed Bożym Narodzeniem 1831 (z Franciszkiem Mickiewiczem) i drugiej w styczniu 1832 (z Wincentym Polem)? 
do landsknechta, preferansa lub do wista. Lecz się umiałem grzecznie wymówić (Rzepecki 1878, 1012-1013).

Rzepecki nie zastał już w Łukowie Adama Mickiewicza, ale interesująca jest wiadomość o większej grupie Litwinów tam goszczących. On sam, lwowianin, nie czuł się zresztą dobrze w ich towarzystwie i wkrótce opuścił dwór Grabowskich, by uczyć się zawodu leśnika. Natomiast Franciszek Mickiewicz osiedlił się nad Wartą na dobre, choć stale marzył o powrocie na Nowogródczyznę, nie chciał też emigrować dalej na zachód.

Bracia Mickiewiczowie spędzili w Łukowie razem Boże Narodzenie, prawdopodobnie też Nowy Rok ${ }^{2}$, w sumie około $10 \mathrm{dni}$; jest to czas dość dobrze udokumentowany, może najlepiej z całego pobytu poety w Wielkopolsce. Kursowały bowiem listy między Łukowem a położonym po drugiej stronie Warty Objezierzem, gdzie wcześniej przebywał Mickiewicz wraz ze Stefanem Garczyńskim u Wincentego Turno. Zachował się także pamiętnik Adama Turno oraz pamiętnik Józefa Grabowskiego (Mikołajtis 1969, Adamczewski 1982).

Nietrudno sobie wyobrazić, iż rozmowy prowadzone w łukowskim dworku głównie dotyczyły Litwy ${ }^{3}$, co wspominał Adam Turno:

Przyjechał także do Łukowa brat jego Franciszek, ułomny, kulawy; ten wypędzony z kraju, bo należał do powstania 1830. Powiadał nam, jaki to zapał był w Litwie i gdyby Wilno wzięte było, Rosja wtedy zgubiona, gdyż za Wilnem tak było urządzone powstanie, iż było 30 domów mających u siebie po 50-60 ludzi i broń, i ludzi zbrojnych, gotowych do powstania (cyt. za: Maciejewski 1972, 382).

Franciszek Mickiewicz nie tylko sam opowiadał, lecz przywiózł ze sobą pamiętnik Ignacego Domeyki pt. Pierwsze dni kwietnia 1831 r. na Litwie; spisany podczas pobytu w obozie pod Elblągiem, gdy Domeyko dowiedział się, że Franciszek jedzie do brata w Poznańskie (Domeyko 1908, s. 185219). Był to zeszyt o 36 kartach, który Mickiewicz czytał w Łukowie i tam pozostawił. Co prawda po kilku latach ponoć słabo sobie przypominał to pisemko ${ }^{4}$, ale wówczas żywa opowieść o sytuacji na Litwie wiosną 1831 i opis dramatycznej przeprawy przez granicę do Królestwa dawnego filomackiego druha z pewnością go poruszyła. Domeyko nie był zesłany

\footnotetext{
${ }^{2}$ Mickiewicz przed odjazdem do Poznania chciał jeszcze raz odwiedzić Objezierze, nie jest jednak pewne, czy udało się te plany zrealizować (niebezpieczeństwa przeprawy przez Wartę o tej porze roku; inna droga wiodła przez Murowaną Goślinę).

3 Warto pamiętać o hipotezie wyjazdu Mickiewicza z Rzymu dopiero na wieść o rozszerzeniu się powstania na Litwę wiosną 1831 oraz planach wyprawy morskiej do Połągi na Żmudź, w której poeta miał wziąć udział (Pol 1871, 143-144; Ruszkowski 1997, 129-133).

${ }^{4}$ Klementyna Grabowska planowała w 1838 roku publikację pozostawionego w Łukowie pamiętnika Domeyki, pisała w tej sprawie do Stefana Witwickiego, który jej odpowiedział 27 lutego 1838: „O pisemku Domejki nie wiem, co odpowiedzieć. Domejko pojechał w tych czasach w bardzo dalekie strony, bo aż do Chili [!], (...). Gdyby pisemko jego drukowano, trzeba by oczywiście opuszczać nazwiska; zresztą pismo to jest mi wcale nieznane, a M.(Mickiewicz) słabo je sobie tylko przypomina”. (Witwicki 1900, 509). Pamiętnik opublikowano dopiero w 1880 w „Kurierze Poznańskim” i osobno (Poznań, Leitgeber, 1880), a następnie ogłosił je Tretiak w 1908. Rękopis przekazany został prze syna Józefa Grabowskiego, Adama, do Ossolineum (Domeyko 1908, V-VI). Na możliwy związek początku Pana Tadeusza (pt. Żegota) z pamiętnikami Domeyki naprowadzają rękopiśmienne notatki prof. Michała Witkowskiego na egzemplarzu książki Maciejewskiego z 1972 roku (egzemplarz w PTPN).
} 
w wyniku procesu filomatów, lecz poddany pod dozór policyjny wzorowo gospodarzył w Zapolu. W kwietniu 1831 otrzymał rozkaz przedostania się jako emisariusz do generała Skrzyneckiego z meldunkiem, że Litwa gotowa jest do powstania. Natychmiast wyruszył z domu. Udało mu się dotrzeć do Puszczy Augustowskiej, gdzie uznany za szpiega cudem ocalił życie. Wiedząc o przedostaniu się do Królestwa innych emisariuszy, powrócił do Zapola. Potem dołączył do działającego na Litwie korpusu generała Chłapowskiego.

Czy w odpowiedzi na lekturę pamiętnika zaczął Mickiewicz już w Łukowie pisać poemacik zatytułowany Żegota (Żegota to odpowiednik imienia Ignacy) $)^{5}$, który z czasem rozwinął się w arcypoemat Pan Tadeusz? Na pytanie to trudno dać jednoznaczną odpowiedź, ale warto je postawić. Łukowskie początki poematu nie były kwestionowane w XIX wieku; dopiero później, może wraz z dołączeniem do wydań Pana Tadeusza wiersza pt. Epilog, zaczęło dominować przekonanie o pisaniu epopei wyłącznie z perspektywy „paryskiego bruku”.

Wkrótce po opuszczeniu Łukowa Mickiewicz pisze do Domeyki list, wysłany 4 stycznia z Poznania, jest to odpowiedź na nieznany list przyjaciela, który musiał ze sobą przywieźć Franciszek Mickiewicz z obozu internowania i w którym Domeyko pisał o pragnieniu powrotu na Litwę. Mickiewicz ma natomiast świadomość bezpowrotnej utraty Litwy... i Marii (ciotecznej siostry Domeyki ${ }^{6}$ ); powściągliwie wyrażona tęsknota, wzruszenie i pogodzenie się ze stratą zdaje się współbrzmieć z tonem inwokacji poematu Żegota, różniącej się zresztą od wersji ostatecznej:

Ojczyzno, Litwo moja, ty jesteś jak zdrowie,

Ileś sercu potrzebna, ten tylko się dowie,

Kto cię stracił; dziś piękność twą w całej ozdobie

Widzę i chcę opiewać, bo tęsknię po tobie.

O związku owego poematu z Domeyką mógłby świadczy nie tylko tytuł, ale i pieczołowitość, z jaką ten przechowywał pierwsze karty rękopisu, wożąc je zawsze ze sobą, nawet na drugą półkulę, do Chile. Wymieniał je jako swoje najdroższe pamiątki:

Między innymi najcenniejsze są pierwsze sied[e]m ćwiartek papieru, na których Adam poczynał pisać Pana Tadeusza, a które odkradłem, dopilnowawszy, kiedy je na czysto przepisał. Na pierwszej kartce jest tytuł Żegota, który potem przemienił (i pamiętam, że nazwisko Saplica przemienił, na Soplica, żeby, jak powiadał, nie ubliżyć w czym żyjącej na Litwie familii Saplica). (...) Na mnie robią zawsze mocne wrażenie te pierworodne litery, w które jednym rzutem pióra wlewał on swoje myśli i natchnienia (Domeyko 1881, 318).

Oczywiście, słowa o „pierworodnych literach” nie przesądzają o tym, kiedy owe litery zostały postawione, Domeyko towarzyszył Mickiewiczowi w Dreźnie i w Paryżu. Jednak istnieje kilka wiarygodnych przekazów,

${ }^{5}$ Domeyko był pierwowzorem Żegoty z III części Dziadów. O pierwszych tytułach Pana Tadeusza zob. m.in. Piechota M., 2000, Od tytułu do „Epilogu”. Studia i szkice o „Panu Tadeuszu”, s. 18-20.

${ }^{6}$ Zapole i Bolcienniki łączyły więzy rodzinne. Matki Ignacego Domeyki i Maryli Wereszczakówny były siostrami (z Ancutów). 
wiążących początki poematu z Łukowem czy szerzej - z Wielkopolską. Najważniejszy jest zapis w pozostających w rękopisie Pamiętnikach z roku 1831 łukowskiego gospodarza, Józefa Grabowskiego:

W domu naszym przebywał m.in. Adam Mickiewicz z bratem, Garczyński Stefan, Pohl7, Zeltner $^{8}$, byli nawet i Pułaski ${ }^{9}$, Szynglarski ${ }^{10}$ oraz wiele innych osób znanych to jako poeci, literaci, to jako figury odznaczające się w ostatnich wypadkach. Adam Mickiewicz w chwilach wolnych od smutku ciężkiego zaczął pisać poema Pana Tadeusza i mnie w nim, choć z anachronizmem daty, umieścił (Grabowski, k. 10 verso).

Drugie zdanie zostało w rękopisie wykreślone, jednak w taki sposób, że jest całkowicie czytelne. Nie jest pewne, czy zrobił to sam Grabowski, czy ktoś inny. Informacje przekazane w pamiętniku są precyzyjne; Mickiewicz rzeczywiście wprowadził do epopei postać oficera napoleońskiego Grabowskiego (Ks. VII), uczynił zresztą w tekście wyraźną aluzję do Łukowa: „(...) blisko Objezierza / polowaliśmy sobie na małego źwierza” (Ks. VII w. 22-23). Ciekawa jest wiadomość o ciężkim smutku gnębiącym poetę, co było prawdą, a czego nie zauważyli inni wielkopolscy gospodarze Mickiewicza. Grabowski, który korespondował z poetą i u którego mieszkał przez kilkadziesiąt lat jego brat, nie potrzebował jakiejś dodatkowej nobilitacji czy tworzenia legendy własnego domu ${ }^{11}$.

Mniej precyzyjny był „przypisek hr. Grabowskiego” do fragmentu listu Adama Mickiewicza pisanego do niego z Drezna 26 [29] kwietnia 1832. Słowa: „Stałem się Schreibsmaschiną i przez całe te kilka tygodni pióra z ręki nie wypuszczam. Jeszcze nie wszystko, com zaczął, pokończone” Grabowski skomentował: „Właśnie pisał Adam w Dreźnie Pana Tadeusza, którego myśl i początek powziął w Łukowie” ${ }^{12}$. Mickiewicz pisał wówczas w Dreźnie III część Dziadów i Redutę Ordona (której pierwsza redakcja powstała prawdopodobnie już w Wielkopolsce podczas pobytu w Choryni).

Drugi przekaz pochodzi od Józefa Bohdana Zaleskiego, który informował syna Mickiewicza, Władysława: „ojciec twój wydumał Pana Tadeusza na wsi w Poznańskiem; tam obmyślił pierwotny plan poematu i zaczął go od opisu dworu szlacheckiego w Polsce" (Zaleski 1875, 7; Dernałowicz 1966, 105-106). Wiadomość tę zamieścił Władysław Mickiewicz w Żywocie: „w Łukowie powziął myśl Pana Tadeusza i pierwsze wiersze tam rzucił na

7 Poeta Wincenty Pol.

8 Franciszek Zeltner (ur. 1795), syn przyjaciela Kościuszki Pierre Josepha Zeltnera (u którego generał gościł w Berville pod Paryżem), w powstaniu 1831 roku ciężko ranny, stracił nogę, został mianowany pułkownikiem. W rodzinie Zeltnerów panował kult Naczelnika.

9 Prawdopodobnie ks. Kazimierz Aleksander Pułaski (1800-1838), pijar, członek Towarzystwa Patriotycznego, naczelny kapelan korpusu gen. Dwernickiego.

10 Ks. Ignacy Szynglarski (1786-1835), proboszcz w Bolimowie w latach 1820-1828, członek Towarzystwa Patriotycznego, kapelan w wyprawie wołyńskiej gen. Dwernickiego.

11 Związany z Łukowem znany historyk literatury Antoni Małecki podawał: „Sam poemat zaczął poeta pisać w zimie 1832 roku, a skończył go, wliczając w to dłuższe przerwy czasu, w lutym 1834” (cyt. za: Winek 2011, 125). Co jednak oznaczała zima 1832? Czy styczeń 1832, czy grudzień 1832 (do grudnia poeta „ukropił tysiąc wierszy”)?

12 Korespondencja Adama Mickiewicza, Paryż 1870-1872, t. 1, s. 58 http://polona.pl/ item/222013/42/Warto jednak dodać, że również Wincenty Pol wspominał o fragmentach Pana Tadeusza czytanych mu przez Mickiewicza w Dreźnie (o sporze Domejki i Dowejki), co uznano za wiadomość niewiarygodną (Dernałowicz 1966, 54). 
papier" (Mickiewicz 1892, 165). W późniejszych badaniach do łukowskich początków poematu pochodzono już znacznie ostrożniej.

Stanisław Pigoń nie wykluczał łukowskiej hipotezy Pana Tadeusza. Zaznaczał jednak, że nie mógł to być obszerny fragment tekstu, według niego „wielkopolski fragment kończył się gdzieś na dzisiejszym w. 174”. Wskazywał, że w redakcji brulionowej Strukczaszy dwa wiersze wcześniej mówi o przyjeździe Tadeusza w niedzielę, a kilka wersów dalej mowa o gościach, którzy właśnie oglądają żniwo. Wyciągał z tego wniosek, iż musiała nastąpić długa przerwa w pisaniu, bo taka niekonsekwencja na przestrzeni 10 wierszy nie byłaby możliwa przy pisaniu ciągłym (Dernałowicz 1966, 106). Z kolei Aleksander Brückner w recenzji Wydania Sejmowego oponował przeciwko wielkopolskim początkom utworu, również odwołując się do autografu: „tylko w pierwszym brulionie, przy samym rozmachu Pegaza, mogła się zjawić niefortunna Elstera ${ }^{13}$. Gdyby poeta zaczął pisać w Łukowie, jak mógłby powtarzać ten lapsus calami w Paryżu i wnet go skreślić" (Brückner 1934, 132). Teresa Winek zwraca jednak uwagę na to, iż w rękopisie jest więcej niekonsekwencji i że Brückner zdawał się nie dostrzegać wewnętrznych niespójności w fabule Pana Tadeusza, tak eksponowanych przez Pigonia i filologów lwowskich (Winek 2011, 261).

Jarosław Maciejewski ostrożnie podchodził do przekazów o wielkopolskich początkach Pana Tadeusza. Sądził, że jeśli rzeczywiście Mickiewicz coś napisał w Poznańskiem, to mogły być to jedynie luźne fragmenty, które potem weszły do poematu, ale poeta nie miał jeszcze obmyślanej żadnej spójnej wizji utworu (Maciejewski 1958, 205). Podobnie umiarkowane stanowisko w tej kwestii zajmowali Maria Dernałowicz (Dernałowicz 1966, 105-106) czy Janusz Ruszkowski (Ruszkowski 1998, 205-206).

W drugiej, poszerzonej wersji książki o pobycie Mickiewicza w Wielkopolsce Maciejewski przyjął bardziej krytyczną postawę. Zestawił ze sobą różne relacje Wielkopolan o pisaniu Pana Tadeusza, dostrzegł ich niekonsekwencje i uznał, że nie przekazują one faktów, a raczej trzeba je wiązać z panującą $\mathrm{w}$ regionie atmosferą kultu poematu. Ostatecznie zawyrokował, że przeważają argumenty „przeciw hipotezie o fazie wielkopolskiej przy pisaniu Pana Tadeusza" (Maciejewski 1972, 334). Tej oceny nie można jednak odnieść do Bohdana Zaleskiego, który potwierdzał wielkopolski rodowód poematu. Dlaczego jednak relacje Wielkopolan Maciejewski uznał za „mocno podejrzane”? Być może odpowiedzi należałoby szukać w procesie przejmowania łukowskiej tradycji przez inne miejscowości. A im bardziej oddalała się ona od pierwotnego źródła i miejsca, tym bardziej nabierała cech legendowych i apokryficznych.

Łukowo nie utrzymało się w rękach Grabowskich, majątek zakupiła w 1859 roku niemiecka rodzina Martinich, Franciszek Mickiewicz mieszkał już wtedy w pobliskim Rożnowie. Nowi właściciele pobudowali w 1877

${ }^{13} \mathrm{~W}$ brulionie w opisie dworu szlacheckiego mowa o wiszącym na ścianie obrazie przedstawiającym śmierć Józefa Poniatowskiego (który zginął podczas przeprawy przez Elsterę w 1813, podczas gdy akcja poematu rozpoczyna się w 1811).

\section{Polonistyka. Innowacje}

Numer 9, 2019 
nowy pałac, a stary dwór został rozebrany. Jeśli więc w jakimś stopniu był pierwowzorem dworu soplicowskiego, „dowód” przestał istnieć. Zupełnie inna była sytuacja w niedalekim Objezierzu. Tradycja rodzinna Turnów bardzo pieczołowicie pielęgnowała pamięć pobytu Mickiewicza w Objezierzu - a także pisania właśnie tam Pana Tadeusza. Na przykład Narcyza Żmichowska zachwycała się objezierskim parkiem-ogrodem; wyobrażała sobie poetę słuchającego śpiewu słowików (Mickiewicz był tam w grudniu!) i szukającego natchnienia do epopei. Realiów wielkopolskich w Panu Tadeuszu można odnaleźć sporo, o czym wielokrotnie pisano. Wspomnijmy tylko niektóre: opowieść Bartka Prusaka o Józefie Grabowskim, który „żył na wsi blisko Objezierza" (ks. VII w. 20-23) ${ }^{14}$, procesy Kwileckich z Turnami (ks. XI w. 318), książka kucharska pana Skórzewskiego z Kopaszewa (ks. XII, brulion), kawiarka ze Śmiełowa (ks. II w. 498-510) ${ }^{15}$, anegdoty łowieckie czy ukształtowanie ziemiańskiego krajobrazu (jakże różnego od tego z Ballad i romansów!). W kolejnych wielkopolskich parkach stawiano ławeczki i sadzono drzewa, które upamiętniały pobyt Mickiewicza. Różne też miejscowości pretendowały do soplicowskiego pierwowzoru: Śmiełów, Choryń, Lubonia, Kopaszewo, Objezierze. Wydaje się jednak, że w rozrastającej się legendzie rozmył się pierwotny przekaz i jakby ukryło miejsce, do którego na przełomie 1831 i 1832 roku zawitała Litwa - Łukowo nad Wartą.

W ostatnich latach wielkopolska tradycja Pana Tadeusza objawiła się z dużym rozmachem. Od roku 1999 w Cichowie pod Lubiniem można zwiedzać Skansen Filmowy Soplicowo i przeniesione tu dekoracje z planu filmowego ekranizacji epopei przez Andrzeja Wajdę. Natomiast od roku 2012 na ziemi kościańskiej oraz w okolicach Śmiełowa realizowany jest projekt Podróże z Panem Tadeuszem, autorstwa Andrzeja Kuźmińskiego. Powstały w ramach tego projektu przewodnik, dzięki atrakcyjnej i sugestywnej szacie graficznej, wpisuje właściwie całego Pana Tadeusza w krajobraz wielkopolski, co oczywiście ma niewiele wspólnego z wcześniejszymi ustaleniami mickiewiczologów.

Pomimo tego zastrzeżenia artykuł chciałby stać się inspiracją do poszukiwania śladów po poecie podróżującym - często w ukryciu i pod zmienionymi nazwiskami - od jednego szlacheckiego dworu do następnego po obszarze całego Wielkiego Księstwa Poznańskiego. Niezależnie bowiem od stopnia słuszności łukowskiej hipotezy pobyt w Wielkopolsce był czasem narodzin pierwszego, może bardzo skromnego, pomysłu późniejszej szlacheckiej epopei - w tej kwestii badacze są zgodni. Pozostaje natomiast pytanie, czy już w Poznańskiem zapisał poeta początkowe wersy poematu.

W Aneksie zebrano w porządku chronologicznym najważniejsze wypowiedzi dotyczące wielkopolskiej hipotezy początku poematu. Na podstawie

\footnotetext{
14 Barbara Kasprzakowa zaproponowała omawianie tej opowieści w gimnazjum w ramach ścieżki regionalnej, przypomniała też wiersz Tadeusza Różewicza Klocek, związany z mickiewiczowską tradycją Śmiełowa (Kasprzakowa 2002, s. 34-41).

15 Według tradycji pierwowzorem kawiarki była pani Ciastowska ze Śmiełowa (Kantecki 1875, 760).
} 
tego materiału można zaproponować uczniom rolę naukowego eksperta - zebrania argumentów przemawiających „za” lub „przeciw” tej hipotezie, próbę ocenienia wiarygodności przytoczonych świadectw i sądów, odpowiedzi na pytanie, czy obecny stan badań pozwala kwestię jednoznacznie rozstrzygnąć, czy pozostaje ona nadal otwarta. Uczniowie mogliby również wybrać najlepsze, ich zdaniem, wypowiedzi ujmujące znaczenie pobytu w Wielkopolsce dla kształtowania się Pana Tadeusza.

\section{Aneks. Wybrane sądy badaczy o łukowskiej hipotezie początków Pana Tadeusza}

Władysław Mickiewicz (1892, 165):

W Księstwie Poznańskim [Mickiewicz] porobił pierwsze spostrzeżenia nad początkującą emigracją, której losy miał dzielić, brzemię jej dźwigając do zgonu. A jednocześnie poznawał warunki bytu Księstwa, przedstawicieli wszystkich warstw Poznańskiego: i magnatów, i drobniejszą szlachtę, i chłopów. Nie dziw więc, że w Łukowie powziął myśl Pana Tadeusza i pierwsze wiersze tam rzucił na papier. Towarzyszył szlachcie na polowaniach, chociaż myśliwym nigdy nie był, ale przysłuchiwał się gawędkom i obznajmiał się dokładniej z obyczajami.

Aleksander Brückner (1934, 133):

Najwyższy czas porzucić bajki łukowskie i nie ubliżać poecie przypuszczeniem, że mógł po r. 1830 marzyć o sielance miłości romantycznej. W Łukowie powziął może plan poematu i zwierzał się z tym gospodarzowi [Grabowskiemu]; tak urosła legenda, jakoby tam zaczął pisać „romantycznego" Pana Tadeusza. (...) Posiadamy przecież brulion paryski i tylko w pierwszym brulionie, przy samym rozmachu Pegaza, mogła się zjawić niefortunna Elstera. Gdyby poeta zaczął pisać w Łukowie, jak mógłby powtarzać ten lapsus calami w Paryżu i wnet go skreślić.

Stanisław Pigoń (1962, XV):

Z odrobiną prawdopodobieństwa można by przypuścić, że ten pierwszy, wielkopolski fragment kończył się gdzieś na dzisiejszym w. 174. W redakcji brulionowej mówi tam Strukczaszy dwa wiersze przedtem, że Tadeusz „nagodził się” „dziś”, „w niedzielę”; a sześć wierszy niżej powiadamia, że goście właśnie oglądają żniwo. Taka niekonsekwencja na przestrzeni dziesięciu wierszy byłaby chyba niemożliwa przy pisaniu ciągłym.

Jarosław Maciejewski (1958, 205):

Zreasumujmy jednak: jeśli bardzo prawdopodobne jest przypuszczenie, że w Wielkopolsce pojawił się w świadomości Mickiewicza pierwszy pomysł poematu szlacheckiego, gdyż dało do tego pobudki bezpośrednie zatknięcie się z polskim życiem dzielnicy oraz obfita lektura polskich książek, to zupełnie niepotwierdzone wydaje się przypuszczenie, że wtedy już obmyślił poeta jakiś epicki plan pierwszej redakcji Pana Tadeusza. Jeśli coś napisał, 
co weszło później do tego poematu, to były to tylko luźne i oderwane od siebie fragmenty liryczne lub opisowe.

Jarosław Maciejewski (1972, 334-335):

Potwierdzenie tych sugestii [Grabowskiego, Zaleskiego] znaleźć można w kilku jeszcze przyczynkach wspomnieniowych: w nekrologu Heleny z Kwileckich Turno pisanym w roku 1874 przez księdza Władysława Chotkowskiego, w rodzinnych wspomnieniach Tomasza Wentwortha Łubieńskiego pisanych w roku 1886 oraz w (...) pamiętniku Heleny Modrzejewskiej, pisanym na przełomie wieków:

[Turnowie] mieli też sobie za obowiązek każdego, który w Wielkopolsce bawił, poetę czy pisarza pod swój dach zaprosić i ugościć i stąd tutaj [w Objezierzu] powstały pierwsze ustępy najznakomitszej polskiej epopei Pana Tadeusza (Chotkowski).

Adam Mickiewicz i Edward Antoni Odyniec dłuższy czas wtenczas [po powstaniu] u niego [u Józefa Łubieńskiego w Pudliszkach] przesiedzieli. Pan Tadeusz był w znacznej części w tym właśnie czasie pisany (Łubieński).

W parku Kopaszewskim jest pewne stare drzewo, pod którym - jak głosi tradycja - nasz wielki Mickiewicz pisał Pana Tadeusza (Modrzejewska).

Autentyczność i pierworodność faktów zawartych w tych przekazach wydaje się mocno podejrzana. Zaleski, rzeczywisty świadek powstawania Pana Tadeusza, mógł mieć przecież od samego autora wiadomości o fazach początkowych poematu, a jednak odwołał się jedynie do relacji Grabowskiego i niczego więcej ponad to nie powiedział, poza wątpliwą hipotezą o pierwszym planie. Genezę pozostałych relacji wyprowadzić zaś trzeba raczej z istniejącej w Wielkopolsce atmosfery kultu tego utworu, niż z wiarygodnych informacji autorów wspomnień.

Maria Dernałowicz (1985, 231-232):

Wśród tych i innych sądów, wypowiadanych o pobycie Mickiewicza w Wielkopolsce, najbardziej przekonywające są te, które nie dotyczą „win” czy „zasług” poety jako konspiratora, działacza politycznego czy też po prostu nie wierzącego w zwycięstwo, nie wiedzącego co mu należy czynić człowieka. Najbardziej przekonywające są głosy, które przypominają, że Mickiewicz wtedy po raz ostatni był w kraju, że słuchał potocznej, żywej polszczyzny, że tłukł się polskimi gościńcami, widział karczmy i wioski, jeździł od dworu do dworu. Znowu zetknął się ze szlacheckim obyczajem, trwającym niezmiennie w ziemiańskich domach, obyczajem podobnym jak ten w Tuhanowiczach czy Rucie; czy bez tych miesięcy wielkopolskich mógłby powstać Pan Tadeusz? Nie ma powodu, by nie wierzyć Bohdanowi Zaleskiemu, gdy pisał po latach do syna poety: „Ojciec twój wydumał Pana Tadeusza na wsi, w Poznańskiem; tam obmyślił pierwszy plan poematu i zaczął go od opisu dworu szlacheckiego w Polsce”. Ile Sopliców zawdzięcza dworkom z Choryni czy Luboni? Miesiące, o których Mickiewicz będzie 
się bał myśleć „jak o chorobie albo o złym uczynku”, były błogosławione dla polskiej kultury.

Teresa Winek (2011, 34-36):

Wersja rękopisowa Mickiewiczowskiego dzieła dokumentowała (...) żmudną pracę autora nad utworem i świadczyła o zmianie pierwotnych zamysłów artystycznych, tym samym zaprzeczała legendzie ${ }^{16}$ poety jako „wielkiego improwizatora”, tworzącego swe dzieła w natchnieniu, gdy „rozbiła się bania z poezją" (...). Skoro tą legendą nie można było objąć Pana Tadeusza, stopniowo budowano inną: o wyjątkowych okolicznościach powstania epopei narodowej. (...)

U narodzin legendy tkwiło pytanie: gdzie i kiedy Mickiewicz zaczął pisać poemat, gdzie pojawił się pierwszy jego zamysł? Świadectwo z korespondencji autora mówiło, że w grudniu 1832 miał on około tysiąca wersów, ale nie wyjaśniało, gdzie powstał pierwszy wers. Otoczenie poety udzielało więc różnych odpowiedzi: początków utworu szukano w Wielkopolsce i w Dreźnie. Na wielkopolskie korzenie poematu wskazywali m.in. Klaczko i Bohdan Zaleski, ten drugi w liście do Władysława Mickiewicza: „Ojciec twój wydumał Pana Tadeusza na wsi, w Poznańskiem; tam obmyślił pierwszy plan poematu i zaczął go od opisu dworu szlacheckiego w Polsce"*. Powoli zwyciężał jednak Paryż jako miejsce tworzenia dzieła i rosła legenda związana z pobytem autora nad Sekwaną.

* Kwestia ta bywa podnoszona także przez dzisiejszych historyków literatury, co potwierdza żywotność problemu i tłumaczy legendę. Bogusław Dopart uznał, że „początek procesu twórczego trzeba by wiązać z pobytem Mickiewicza w Wielkopolsce” (Bogusław Dopart, 1999, Czem był "Pan Tadeusz" dla Polaków w dobie niewoli, w: W świecie "Pana Tadeusza”, Kraków) oraz: „Według wiarygodnej tradycji pierwsze wersy Pana Tadeusza naszkicował poeta jeszcze w Wielkopolsce" (Adam Mickiewicz, w: Historia literatury polskiej. V. Romantyzm. Część pierwsza, 2006, Bochnia-Kraków-Warszawa, s. 343). Bardziej umiarkowane było stanowisko Jarosława Maciejewskiego.

\section{Bibliografia:}

Adamczewski Zbigniew, 1982, Objezierze i jego legenda literacka, praca magisterska napisana pod kierunkiem prof. Zofii Trojanowiczowej (maszynopis UAM).

Bełza Władysław, 1890, Brat poety, „Pamiętnik Towarzystwa Literackiego im. Adama Mickiewicza", R. IV, s. 185-191.

Brückner Aleksander, 1934, Wydanie Sejmowe Mickiewicza, „Rocznik Literacki”.

Dernałowicz Maria, 1985, Adam Mickiewicz, Warszawa.

${ }_{16}$ Definicję „legendy literackiej” przejmuje autorka od Andrzeja Z. Makowieckiego i rozumie jako „rodzaj potocznej, społecznej recepcji zjawiska literackiego, dzieła lub biografii twórcy, recepcji bliższej emocjonalnej akceptacji lub odrzuceniu niż poznaniu naukowemu". 
Dernałowicz Maria, 1966, Od „Dziadów” części III do „Pana Tadeusza”. Marzec 1832 - czerwiec 1834, Warszawa.

Domeyko Ignacy do Antoniego Edwarda Odyńca, 1881, „Kłosy”, nr 855, s. 318 http://polona.pl/item/7942644/12/

Domeyko Ignacy, 1908, Pierwsze dni kwietnia 1831 r. w Litwie, w: Pamiętniki Ignacego Domejki (1831-1838), z autografu wydał J. Tretiak, Kraków, s. 185-219. http://polona.pl/item/1088499/101/

Grabowski Józef, O wypadkach roku 1831, rkps Ossolineum 4200/ II.

Kantecki Klemens, 1875, Mickiewicz w Śmiełowie. „Ruch Literacki” nr 47-48, przedruk: „Kurier Poznański”, nr 272, 276. http://www.wbc.poznan.pl/dlibral publication? id $=85665 \&$ tab $=3$

Kasprzakowa Barbara, 2002, Naucz się dziwić. Literatura i sztuka. Podręcznik do klasy drugiej gimnazjum, Poznań.

Kuźmiński Andrzej, 2012, Podróże z Panem Tadeuszem, Pępowo. http://podrozezpanemtadeuszem.pl/przewodnik-turystyczny.html

Maciejewski Jarosław, 1958, Gdy gościł w Wielkopolszcze. Adam Mickiewicz w Wielkim Księstwie Poznańskim. 1831-1832, Poznań.

Maciejewski Jarosław, 1972, Mickiewicza wielkopolskie drogi. Rekonstrukcje i refleksje. Poznań .

Mann Maurycy, 1904, Wincenty Pol. Studium biograficzno-krytyczne, t. 1, Kraków.

Mickiewicz Władysław, 1892, Żywot Adama Mickiewicza, t. 2, Poznań.

Mikołajtis Józef, 1969, Niektóre szczegóły z pobytu Mickiewicza i Garczyńskiego w Poznańskiem $w$ świetle korespondencji i rękopisów, „Komunikaty Naukowe. Towarzystwo Literackie im. A. Mickiewicza. Oddział Częstochowski", nr 10-12, s. 1-99.

Na tropach Adama Mickiewicza w Wielkopolsce, 2013, Borowczyk J., Dambek-Giallelis Z., Lijewska E. (red.), Poznań.

Pigoń Stanisław, 1962, Wstęp, w: Adam Mickiewicz, Pan Tadeusz, Wrocław (BN I 83).

Pol Wincenty,1871, Wiersz Adama Mickiewicza niedrukowany dotąd, „Strzecha”, s. 142-145 https://jbc.bj.uj.edu.pl/dlibra/doccontent?id=386258

[Rzepecki Kajetan], 1878, Pamiętniki starego żołnierza napisane przez Białyniaka, Poznań.

Ruszkowski Janusz, 1998, Czy Mickiewicz był w Wielkopolsce? w: Księga Mickiewiczowska. Patronowi uczelni $w$ dwusetna rocznice urodzin 1798-1998, Poznań, s. 247-268.

Ruszkowski Janusz, 1997, "Jutrznia oswobodzenia nad Litwa”, czyli Mickiewicz w czasie powstania listopadowego, w: Nie tylko o Norwidzie, Czarnomorska J., Przychodniak Z., Trybuś K. (red.), Poznań, s. 123-139.

Ruszkowski Janusz, 1998, Kronika życia i twórczości Adama Mickiewicza. Poznańskie: 1831-1832, (maszynopis, IBL Warszawa). 
Winek Teresa, 2011, „Pan Tadeusz” Adama Mickiewicza. Autografy i edycje, Toruń-Warszawa.

Witwicki Stefan, 1900, Trzy listy do Klementyny z Wyganowskich Grabowskiej, „Roczniki Poznańskiego Towarzystwa Przyjaciół Nauk”, t. 26, s. 509. http://www.wbc.poznan.pl/dlibra/doccontent?id=118607\&from $=F B C$

Zaleski Józef Bohdan, 1875, Adam Mickiewicz podczas pisania i drukowania „Pana Tadeusza”. List do syna Adama, Paryż.

https://www.pbc.rzeszow.pl/dlibra/publication/1327/edition/1242/ content?ref=desc

\section{O Autorce:}

Elżbieta Lijewska, dr, dokumentalistka, pracuje w Instytucie Filologii Polskiej Uniwersytetu im. Adam Mickiewicza, autorka rozprawy Szkice Kaukaskie. O twórczości wygnańczej Władysława Strzelnickiego (1998), współautorka Kalendarza życia i twórczości Cypriana Norwida (2007), redaktorka przewodnika literackiego $\mathrm{Na}$ tropach Adama Mickiewicza w Wielkopolsce (2013), należy do zespołu przygotowującego bibliografię Adama Mickiewicza w serii „Nowy Korbut”. Ponadto należy do komitetu redakcyjnego lubelskiej edycji Pism wszystkich Norwida. 